and important rôle in the maintenance of efficiency, such as lighting, heating, ventilation, the mode of life led by the worker outside his definite hours of labour, his housing, etc. Many of these factors have been partially examined. Thus Leonard Hill has carried out a great deal of valuable work on the influence of the cooling power of the air. Vernon has collected much interesting evidence, which shows that there is a very definite relation between the efficiency, as measured by output, and the temperature of the working place. The output in the hottest weather was about 30 per cent. below that when the weather was coldest. He also observed an apparent connexion between the relative humidity of the air and the efficiency of the worker. The efficiency, as might have been expected, was apparently greatest when the relative humidity was low. Elton has reported on the influence of lighting in silk weaving. He found that the output was lowest when artificial light was used. He stated that even when electric light of sufficient intensity was used, the output was about Io per cent. lower than the daylight value. The actual equipment of the factories, the provision of seats of suitable size, height, etc., the design of the machines, and so on, all play their part, as is shown by the many records, particularly from the United States.

In other words, the real over-all industrial efficiency of the worker cannot be causally related to any single factor. It is not the mere capacity of the individual to perform so many kilogram-metres of work in a given time with the smallest expenditure of energy. The quest of efficiency calls for the closest and most intimate co-operation between the scientific investigator, the employer, and the employee, and it can only be satisfactorily attacked when mutual distrust of motives, capacities, and methods is stilled.

\title{
The Total Solar Eclipse of September 2I.
}

\author{
By Dr. A. C. D. Crommelin.
}

$\mathrm{T}^{\mathrm{H}}$ E failure of the Christmas Island eclipse expedition is a great astronomical disappointment. Messrs. Jones and Melotte have devoted ten months or more to it, and hoped to secure useful photometric results for connecting the northern and southern stellar magnitude scales in addition to the eclipse work. The climate, however, proved unexpectedly unfavourable, and practically nothing could be done.

On the other hand, the conditions appear to have been ideal right across Australia, and enthusiastic reports have come from Wollal (West Coast), Cordillo Downs (centre), and Goondiwindi and Stanthorpe (Queensland). The Einstein problem was studied at Wollal by the Lick Observatory party under Prof. Campbell, and that from Toronto under Prof. Chant. Mr. Evershed also finally selected this station in preference to the Maldives, and is believed to have undertaken the same investigation, in addition, doubtless, to spectroscopic work. Prof. Dodwell, the Government Astronomer at Adelaide, had the use at Cordillo Downs of a tower telescope lent by the Lick Observatory for the Einstein problem; the New South Wales astronomers were in Queensland and did some spectroscopic work; they intended also to make Einstein investigations, but the telegrams do not allude to these.

It is well to point out that the test of the Einstein theory does not depend wholly on the results of this eclipse. The plates secured in the I9I9 eclipse at Principe and Sobral settled definitely that at least the half-shift was present, while the two cameras with the best definition gave values very close to the Einstein value. Further, the star-field in that eclipse was the best along the whole extent of the ecliptic, the stars in the present eclipse being much fainter. There are, however, two circumstances that should add weight to this eclipse: (I) that some of the observers were pointing directly on the stars, avoiding the use of a cœlostat or other mirror ; (2) that the plan was being tried of photographing another star-field during totality, thus obtaining an independent scale-value for the plates, which gives a much larger coefficient to the Einstein displacement in the equations of condition.

Probably weeks or months must elapse before the Einstein results are to hand.

The corona is said to have had four long streamers, one extending to three solar diameters, which is more than the average, though by no means a record.

Prof. Chant reports that the shadow bands were photographed. Prof. Kerr Grant, of Adelaide University, made measures at Cordillo by the photoelectric cell of the relative brightness of the sun and the corona. The results, with this very sensitive instrument, should be more trustworthy than previous determinations.

The next two total eclipses (r923, September, and I925, January) are visible in the United States; 1926, January, in Sumatra, etc., and 1927 in England and Norway.

\section{Obituary.}

\section{Prof. Alexander Smith.}

ALEANDER SMITH, emeritus professor of chem$A$ istry in Columbia University, New York, died in Edinburgh on September 8, aged fifty-seven, Smith was born in Edinburgh, and entered the University there in 1882, where he studied mathematics under Chrystal, natural philosophy under Tait, and chemistry under Crum Brown, graduating as B.Sc. in 1886 . During the following three years he attended the University. of Munich, working in Baeyer's laboratory, chiefly under the direction of Claisen, and obtained the degree of Ph.D. in I889.

After a year spent as assistant in the chemistry department of the University of Edinburgh, Smith was offered the chair of chemistry and mineralogy in Wabash College, Indiana, a post which he held for four years. In 1894 he became assistant professor of 
chemistry in the University of Chicago, and rose through intermediate grades to that of professor and director of general and physical chemistry in 1903 . Here his extraordinary gifts as organiser and teacher found ample scope. His "Laboratory Outline of General Chemistry" was published in 1899 , since when at short intervals new text-books or new editions flowed from his pen. Each book had in view the requirements of students of a definite stage of development, and all were characterised by an orderliness of method, combined with an originality of thought, which have made them popular not only throughout the English-speaking world but also as translations in almost every country where science is studied. An even wider field was offered to him in the principal chair of chemistry in Columbia University in the City of New York, where he became director of the department of chemistry. Here he may be said to have revolutionised the methods of teaching and the organisation for chemical research.

Smith at the outset of his career was an organic chemist, and until I902 his published papers are all concerned with organic topics, chiefly the chemistry of diketones, the benzoin reaction, and, generally, the action of potassium cyanide as a condensing agent. After 1902 his work is inorganic and physico-chemical, the physical character of his investigations becoming more and more marked with the lapse of years. An admirable series of papers on the liquid and amorphous modifications of sulphur formed the first-fruits of his cultivation of this new field. Chiefly in conjunction with A. W. C. Menzies, now professor of chemistry at Princeton, Smith published a long series of papers on vapour pressures, many new devices for their exact measurement and for the measurement of boilingpoints under standard conditions being described. Among the valuable data obtained may be noted the exact determinations of the vapour pressure of mercury from $250^{\circ}$ to $435^{\circ} \mathrm{C}$. The vapour pressures of dissociating substances such as ammonium chloride, calomel, and phosphorus pentachloride were also measured and discussed, particularly in connexion with the unexpected values obtained when the substances were perfectly dry. His scientific merit was recognised by his election to membership of the National Academy of Sciences, and to the Presidency of the American Chemical Society. In Igrg the honorary degree of LL.D. was conferred upon him by the University of Edinburgh.

Smith was a most genial personality, a pleasant companion, and a delightfully amusing talker. He was filled to overflowing with energy, which in the end proved his undoing. A breakdown owing to overwork, complicated by a serious operation, forced him after a year's leave to relinquish his chair, and his death at a comparatively early age deprives his science of a great teacher whose name will not soon be forgotten.

J. W.

\section{Dr. Sophie Bryant.}

By the death of Dr. Sophie Bryant in the Alps last month the educational world has lost a great personality. As mathematician, philosopher, Irish patriot, suffragist, and, above all, as a teacher and pioneer in education, she had gained distinction in so many fields that it is difficult to give any adequate account of her in a few paragraphs.

Mrs. Bryant in her own person gave the lie to the old conception of the unwomanly "bluestocking." Her greatness of intellect was shot through with a warmth of genial humanity and an endearing charm that those who knew her can never forget. She came of a scholarly stock : her father, Dr. Willock, a clergyman of the Church of Ireland in Co. Fermanagh, worked in the cause of education there. After his death the family moved to London, and his brilliant daughter distinguished herself by obtaining, at the age of sixteen, first-class honours in the Senior Cambridge Local Examination, with distinction in mathematics, and an Arnott scholarship at Bedford College. It was only after her marriage and early widowhood that she became acquainted with Miss Buss, and, having joined the staff of the North London Collegiate School in 1875 , was one of the first to take advantage of the opening of London University degrees to women. After matriculating in honours in 1879 (with the distinction of being placed second on the list), in two years she had obtained the B.Sc. with honours in mathematics and moral science, and three years later was the first woman to gain the doctor's degree of London University, her subject being mental and moral science. She used to relate an amusing story about this :- one of the two examiners wrote to his colleague, "There's a very good man in;" the other, who knew Mrs. Bryant, replied, "Your man's a woman!"

Ten years later, in r894, Mrs. Bryant was appointed to sit on the Royal Commission for Secondary Education, of which Lord Bryce was chairman. In I 900 she became a member of the Consultative Committee of the Board of Education, and in the same year took her seat on the Senate of London University. From I 908 to 19I4 she was a member of the London Education Committee.

During all this time she was, in a very real sense, a "guide, philosopher, and friend" to her pupils at the North London Collegiate School; the writer of this article is one of many whose debt to her in this respect is beyond all reckoning. When in 1895 Mrs. Bryant succeeded Miss Buss as head-mistress, her mathematical teaching perforce devolved to a large extent on her colleagues, but she remained the guiding moral force in the school, explicitly through her Scripture lessons and weekly addresses, but implicitly in all that she did. She was a pioneer in the revitalising of Scripture teaching, bringing to bear on religious instruction the same psychological insight and width of outlook by which she and her fellow-reformers brought life into the dry bones of the educational curriculum. Of this work she has left a permanent memorial in her books: "The Teaching of Morality in the Family and the School," "The Teaching of Christ in Life and Conduct," "How to read the Bible in the Twentieth Century," "Moral and Religious Education."

Mrs. Bryant was a devoted Irishwoman, and perhaps no honour pleased her more than the degree of doctor of literature, honoris causa, bestowed upon her by Trinity College, Dublin, when first it opened its degrees to women. Her love of Ireland also found expression in her writings : "Celtic Ireland," "The Genius of the 